\title{
ANALYSIS OF THE OUTER PART MICROFLORA OF THE SEEDS OF MELON CROPS AND THE EFFECT OF SEED TREATMENT PREPARATIONS
}

\author{
Alimukhamedov Saidmurat Sultanovich \\ Senior Research Officer, Candidate of Biological Sciences, Scientific-Research Institute of \\ Vegetable, melon and potato growing, Tashkent district, Tashkent region, Uzbekistan
}

\author{
Kholdorov Mirkhalil Urazbekovich \\ Senior Research Officer, Candidate of Biological Sciences, Scientific-Research Institute of \\ Vegetable, melon and potato growing, Tashkent district, Tashkent region, Uzbekistan
}

\author{
Akhmedova Munisa Abdumajitovna \\ Independent Researcher, Scientific-Research Institute of Vegetable, Melon and Potato Growing, \\ Tashkent district, Tashkent region, Uzbekistan
}

Article DOI: https://doi.org/10.36713/epra5138

ABSTRACT

This article reveals the results of experiments on microbiological analysis of harmful microorganisms present in the outer shell of melon and watermelon seeds in order to select seed treatment preparations.

In the republic, sowing of seeds of vegetable and melon crops after having the treatment with particular preparations in the open field is not allowed. Because of this, seeds produced in our conditions are planted without chemical treatment, and the spread of the disease in the cultivated plants is leading to a sharp decline in productivity.

KEYWORDS: melon, watremelon, seed, microflora, seed treatment preparations, preparation, bacteria, actinomycetales, fungus..

\section{INTRODUCTION}

One of the reasons for the spread of the disease is the pathogens of fungi, bacteria and viruses that remain in plant seeds and soil. The most damaging viral diseases in tomatoes and cucumbers occur mainly in seeds and soil $[2,5,6]$.

In modern seed production technology, plant protection control measures are aimed at preventing the spread of insects, fungal, viral and bacterial diseases.

The plant protection system is designed for preventive measures and eradication, serves to clean the plant residues in open and closed areas, to clean the technical organs, to apply chemical or thermal treatment of insects and diseases $[1,4,6]$.

Treatment of melon seeds with preparations formalin and granozan against pests and diseases (NIUIF-2) has high effectiveness [3].

\section{MATERIALS AND METHODS}

Microbiological analysis of what harmful microorganisms are present in the outer part of melon and watermelon seeds is one of the main factors. For microbiological analysis of melon seeds, $1 \mathrm{~g}$ of each sample was weighed, ground in a mortar, and thoroughly mixed for 10 minutes in $10 \mathrm{ml}$ of sterilized 


\section{EPRA International Journal of Research and Development (IJRD) \\ Volume: 5 | Issue: 9 | September 2020 - Peer Reviewed Journal}

water.

In the separation of bacteria, $1 \mathrm{ml}$ of the prepared solution was placed in a sterilized Petri dish, $10 \mathrm{ml}$ of artificial nutrient MPA was added to it and incubated for 2-3 days at a temperature of $28-30{ }^{\circ} \mathrm{C}$ in a thermostat. For isolating the fungi, $1 \mathrm{ml}$ of the prepared solution was poured into a sterilized Petri dish, over which $10 \mathrm{ml}$ of artificial Czapek media was added and incubated in a thermostat at $28-30{ }^{\circ} \mathrm{C}$ for $5-7$ days.

\section{RESULTS AND DISCUSSION}

In the separation of actinomycetales, $1 \mathrm{ml}$ of the prepared solution was placed in a sterilized Petri dish, on top of which $10 \mathrm{ml}$ of artificial ammonia starch was added and incubated in a thermostat at $28-30{ }^{\circ} \mathrm{C}$ for $5-6$ days. To determine the outer microflora of the seeds, the above-mentioned artificial media was poured into a sterilized Petri dish and incubated for 3-4 days at a temperature of $28-30{ }^{\circ} \mathrm{C}$, after placing in it the melon seeds (Table 1).

Table-1

Analysis of outer part microflora of melon crop seeds

\begin{tabular}{|c|c|c|c|c|c|c|c|c|c|}
\hline \multirow[b]{2}{*}{ Crop } & \multicolumn{3}{|c|}{ BPA } & \multicolumn{3}{|c|}{ SAA } & \multicolumn{3}{|c|}{ Czapek agar } \\
\hline & 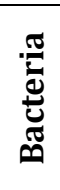 & 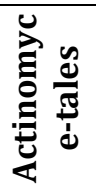 & 菢 & 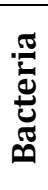 & 冚 & $\underset{\Xi}{\Xi 50}$ & 宽 & 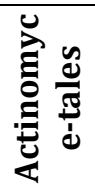 & 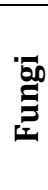 \\
\hline Melon & 11 & - & 5 & 4 & - & 2 & 3 & 3 & 5 \\
\hline Watermelon & 12 & - & 11 & 5 & - & 2 & 3 & 2 & 5 \\
\hline
\end{tabular}

When analyzing the outer microflora of melon crop seeds, in BPA - beef peptone agar nutrient media more than 11 bacteria and 5 fungi, in SAA- starch ammonia agar media 4 bacteria and 2 fungi, in Wort agar media 1 actinomycetale and in Czapec agar media 3 bacteria, 3 actinomycetales and 5 fungi were isolated.

When analyzing the outer microflora of watermelon seeds, 12 bacteria and 11 fungi were isolated in MPA - meat peptone agar media, 4 bacteria and 5 fungi in starch-ammonia media, 1 actinomycetale in Wort agar media, 3 bacteria, 2 actinomycetales and 5 fungi were isolated in Czapec agar media.

After the treatment of melon seeds (the 15th day) with chemical and microbiological preparations, development of outer microflora of seeds was analyzed and determined (Table 2, Fig. 2).

Table-2

The effect of seed treatment preparations on the microorganisms in outer microflora of melon seeds

The effect of seed treatment preparations on the microorganisms in outer microflora of melon seed
\begin{tabular}{|l|c|c|c|c|}
\hline & \multirow{2}{*}{$\begin{array}{c}\text { Application rate, } \\
\text { g/ml/kg }\end{array}$} & Bacteria & $\begin{array}{c}\text { Actinomy- } \\
\text { cetales }\end{array}$ & Fungi \\
\cline { 4 - 5 } & 5 & - & - & - \\
\hline Maxim, 3.5\% SC. & 5 & - & + & - \\
\hline Seles Top, 31.2\% SC & 3 & - & - & - \\
\hline Hercules, 6\% WSC & 3 & - & + & \\
\hline Vial TT, 12.9\% WSC & 6 & - & - & + \\
\hline Bronopol, 12\% P & 7 & - & - & + \\
\hline Bronopol, 12\% P & 3 & - & - & - \\
\hline Gaucho gold, 35\% WP & 5 & - & - & - \\
\hline Gaucho gold, 35\% WP & 1,4 & - & - & - \\
\hline Kuklam-1 liquid & 1,4 & - & - & - \\
\hline Kuklam-2 liquid & 1 & - & - & - \\
\hline Trichodermin & Thermal & + & + & + \\
\hline Control (thermal treatment) & Without treatment & + & + \\
\hline Control & & & & + \\
\hline
\end{tabular}




\section{EPRA International Journal of Research and Development (IJRD)}

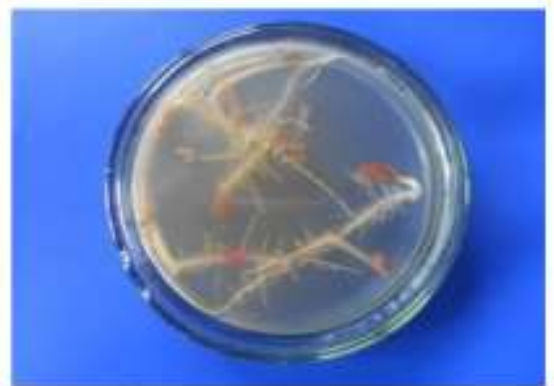

Maxim, $3.5 \% \mathrm{SC}-5 \mathrm{~mL} / \mathrm{kg}$

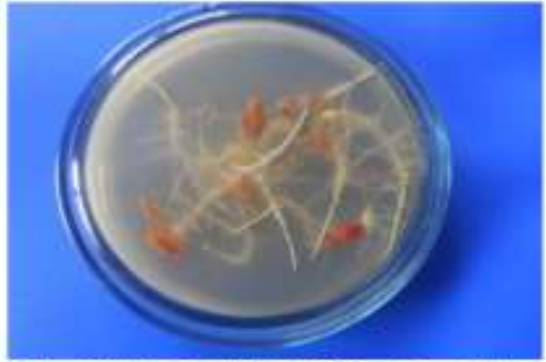

Vial TT, $12.9 \% \mathrm{WSC}-3 \mathrm{ml} / \mathrm{kg}$

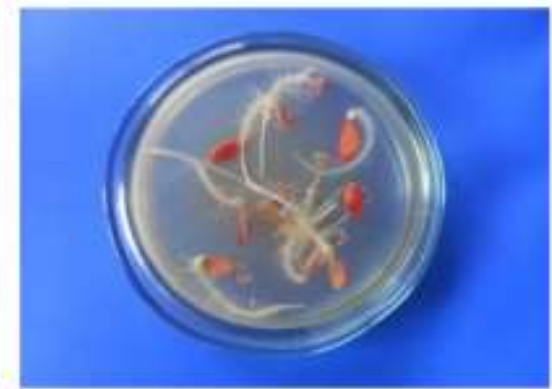

Seles Top, $31,2 \% \mathrm{SC}-5 \mathrm{mLkg}$

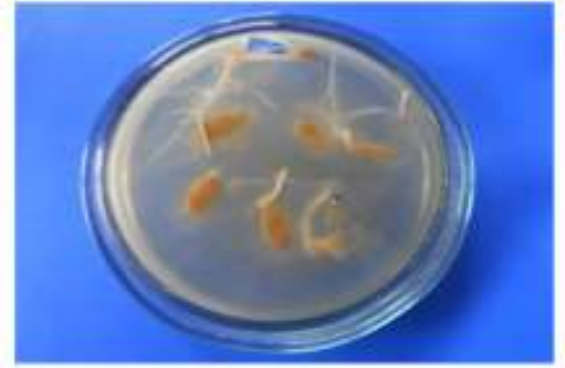

Bronopol, $12 \%$ P - $6 \mathrm{~g} / \mathrm{kg}$

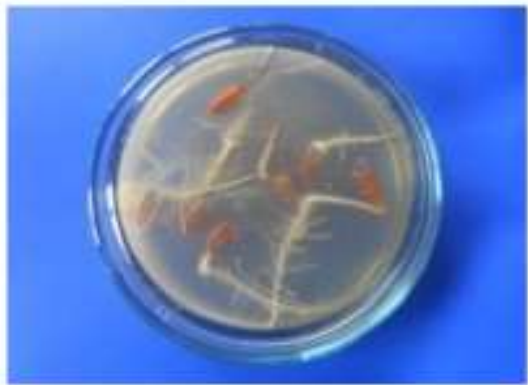

Hercules, $6 \% \mathrm{WSC}-3 \mathrm{~mL} / \mathrm{kg}$

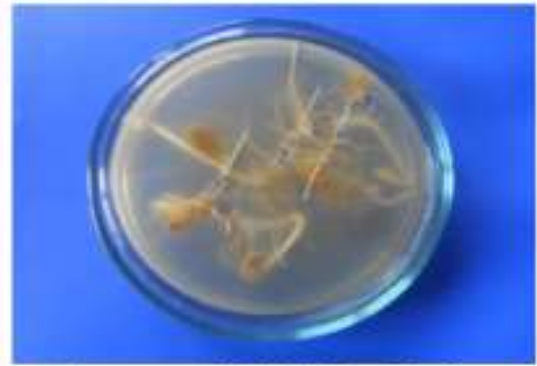

Bronopol, $12 \% P-7 \mathrm{~g} / \mathrm{kg}$

Fig. 2. Results of analysis of outer part micloflora of melon seeds

According to the results of microbiological analysis, when determining the development of outer part microflora of the seeds in artificial nutrient media condition, no any microorganism development was observed in the variants in which the preparations Maxim, 3.5\% SC - $5 \mathrm{ml} / \mathrm{kg}$, Hercules, $6 \% \mathrm{WSC}-3$ $\mathrm{ml} / \mathrm{kg}$, Gaucho gold, 35\% WP - $3 \mathrm{~g} / \mathrm{kg}$, Gaucho gold, $35 \%$ WP - $5 \mathrm{~g} / \mathrm{kg}$, Microgrower "Kuklam 1" - 1,4 $\mathrm{ml} / \mathrm{kg}$, Microgrower "Kuklam 2" $-1,4 \mathrm{ml} / \mathrm{kg}$ were being tested. But, in Bronopol, $12 \% \mathrm{P}-6 \mathrm{~g} / \mathrm{kg}$, Bronopol, 12\% P - $7 \mathrm{~g} / \mathrm{kg}$ variants, Aspergillus and Penicillum families related species of fungi were found.

In experimental variants with preparations Seles Top, 31,2\% SC - $5 \mathrm{ml} / \mathrm{kg}$, Vial TT $12.9 \%$ WSC - 3 $\mathrm{ml} / \mathrm{kg}$, actinomycetales were found, in control (with thermal treatment) variant actinomycetales and fungi, in other control variant (without treatment) bacteria, actinomycetales and fungi were found.

\section{CONCLUSIONS}

Based on the data obtained it was known that bacteria, fungi and actinomycetales were separated from the outer part of the melon seeds. For this analysis, fungicides were used for seed treatment to clean the outer part microflora of melon seeds from primary microorganisms.

According to the data obtained, the microbiological analysis of melon seeds showed that the most common microorganisms found belonged to Bacillus, Pseudomonas family of bacteria, and Aspergillus, Penicillum families of micromycetes.

\section{REFERENCES}

1. Golishin N.M. 1982. Fungicides. Moscow, Kolos, 272 p.

2. Pankova K.V. 2005. General phytopathology. Moscow, 448 p.

3. Pestsov S.T., Borisova N.S. 1995. Damage on tomato varieties caused by fusarium. Tashkent, pp.51-53.

4. Pidoplichko N.M. 1977. Fungi - parasites of cultural plants. Identification Guide (Opredelitel) I, II, II vol. - Kiev, pp. 249-252.

5. Pospelov S.M., Berim I.G., Vasilyeva E.D., Persov M.P. 1986. Plant protection, Moscow, Agropromizdat, $391 \mathrm{p}$.

6. Vlasov Yu.I. 1960. Viral diseases of vegetable and melon crops in Uzbekistan. Tashkent, pp. 312 